\title{
Fugitive monuments and animal pathways: explaining the stone settings of Exmoor.
}

\author{
Mark Gillings \\ School of Archaeology \& Ancient History \\ University of Leicester \\ Leicester
}

LE1 7RH

mg41@le.ac.uk

\begin{abstract}
As a result of the exclusive use of extremely small megaliths (miniliths) the prehistoric stone settings of Exmoor, SW England, challenge current approaches to the interpretation of monumental stone architecture during the later Neolithic and early Bronze Age. Whilst the broader context of the practice of erecting tiny upright stones (a seemingly diverse and widespread phenomenon) and the reasons why this diminutive architecture has tended to escape sustained critical comment have been explored (smaller stone elements being relegated to a generalised background or subsidiary role such as 'packing'), attempts to explain the settings have been remarkably few. Drawing upon the results of ten years of piecemeal fieldwork on the moor the present paper seeks to rectify this, arguing that far from generalised ritual structures or metaphorical expressions of hunting groups, the tiny stones were instead an integral part of a dynamic human-animal landscape of movement and pause.
\end{abstract}

\section{Key words}

Miniliths, monuments, landscape, affordance, visibility, hiding, framing, movement, animals, concealment

\section{Introduction}

This is the second of two synthetic papers arising from a ten year program of piecemeal survey and excavation carried out on the prehistoric monuments of Exmoor, southwest England; monuments constructed using deliberately small, inconspicuous stones. The first of these explored the broader context of the practice of erecting tiny uprights, demonstrating that far from being unusual, the tradition of raising small stones was widespread and long-lived, being manifested in a host of monumental forms. That this diminutive architecture has tended to escape sustained critical comment was seen in large part as the result of an archaeological 
tendency to equate monumentality with size alone, with a concomitant propensity to relegate smaller stone elements to a generalised background or subsidiary role such as 'packing' (Gillings in press). As a result of their reliance upon extremely small megaliths (miniliths) the Exmoor stone settings force us to confront this issue directly and think creatively about the limitations it in turn imposes upon our approaches to classification and the character of stone architecture during the later Neolithic and early Bronze Age. Whilst this first discussion served to draw attention to the ubiquity of such monuments and the problems we encounter in recognising them and affording them critical analysis, it did not make any sustained attempt to explain what the stone settings were for. The present paper seeks to rectify this, drawing upon their morphology, broader landscape context and the results of the fieldwork carried out to date to offer an interpretation of at least some of Exmoor's diminutive monuments.

\section{Introducing the stone settings}

Exmoor's settings comprise discrete clusters of standing stones thought to date to the late Neolithic or early Bronze Age; a local manifestation of a more widespread phenomenon that witnessed the emergence of a host of new, distinctive monumental expressions in many upland areas, involving the manipulation of standing and recumbent stones into rows and circles, alongside the gathering and modelling of piles of stone (into cairns, ring-cairns and spreads). What is unusual about the Exmoor structures is their consistent use of very small uprights (typically $0.3 \mathrm{~m}$ or less in height) often accompanied by distinctive projecting packing stones called 'triggers' and their seemingly regular geometric and semi-geometric forms that have no obvious parallels. To date 59 such settings have been identified, many concentrated around the headwaters of valleys (for more detailed discussions of the stone settings see Riley and Wilson-North 2001; Gillings et al. 2010; Tilley 2010). The subject of the present paper is a group of 5 settings over-looking a tributary of Hoccombe Water; Lanacombe I-IV and the new Trout Hill setting (Quinnell and Dunn 1992, 44-5; Riley 2007; see Figure 1 and Table 1). They are part of a particularly dense cluster of 14 settings in the upper reaches of Badgworthy Water; Riley and Wilson North's Landscape Study Zone 3 (2001, 31) and have been the focus of the most sustained episodes of the current fieldwork (Gillings et al. 2010; Gillings 2013; Gillings and Taylor 2011a).

\section{Explaining the stone settings}

The earliest explanations for the stone settings were usefully collated by Chanter and Worth in the early years of the last century in the context of their pioneering measured surveys. 
These tended to fall into two distinct camps - either druidical and/or sepulchral antiquarian musings or common-sense folk wisdom; the former identifying them with commemorative monuments or druid pathways, the latter practical tools for the gathering and counting of sheep (1905, 376-390). In his survey of 1970 Grinsell elected to include them as a tentative category within his discussion of Bronze Age stone monuments, refusing to speculate as to their purpose. By the late $20^{\text {th }}$ century this association between settings and Neolithic-Bronze Age stone monuments was more clearly drawn, with the clusters of small standing stones listed alongside stone circles, rows and isolated or paired standing stones and presumed to have served a non-specified ritual/symbolic role (Riley and Wilson-North 2001, 23-31). Hedging their bets, Gillings et al. were content to merely highlight a number of potentially useful frameworks for thinking about the settings (marking; memorialisation; framing and materiality) stressing the interpretative challenges laid down by their 'underwhelming presence' and intimate, personal scale (2010, 315-6).

The most sustained attempt to interpret the stone settings was carried out by Tilley in the context of an extensive programme of phenomenological investigation (Tilley 2010, 293347). Rather than incorporating them alongside other more familiar monumental manifestations, Tilley stressed their difference, reflecting a much more local and idiosyncratic set of relationships between people and place than the more familiar cairns, rows and circles. His argument was that the settings served to emplace and materialise the organisation and structure of hunting parties at those locations in the landscape most efficacious for watching for (and hunting) game - in this case red deer. The settings indicated named places in the landscape with individual stones representing individual hunters, the setting as a whole a powerful material metaphor and source of moral authority, reflecting the social organisation of the hunting group as well as serving to anchor stories and memories. To Tilley the stones of the settings 'added power and significance, historical depth and moral authority' to these places (ibid, 339). Further, parallels were drawn between the number and configuration of the stones (hunters) and the branching structure of stag antlers, the implication being that stags were not only revered but that the form of the settings also served to materially embed the significance of the stag into the landscape. Like Chanter, Worth and Burl before, to Tilley the settings were first and foremost profoundly geometric structures, with any deviations from regularity a result of taphonomy and partial preservation (ibid, 308). Whilst they were assumed to be Neolithic-Bronze Age in date they were not necessarily fixed structures, raised in a single episode and remaining static in the landscape. Instead, changes 
in group organisation and the relative efficacy (or otherwise) of a given hunting locale over time would inevitably result in alteration and modification, albeit within a rigidly geometric template.

Tilley's hunting interpretation is based primarily upon visual characteristics; not of the settings (whose stones are largely hidden from view - even from one another within certain settings) but instead the locations in which we find them. These shared a tendency to fall on mid-slopes away from ridges and hilltops, giving them a directionally constrained 'dominant' or 'primary' view (2010, 340, Figure 7.25). To Tilley they 'appear to mark places with excellent vantage points along and across stream valleys and parts of the moor' (ibid, 335). These were locations where at certain times of the year Red deer would move between the valleys and high moor and as a result were places people looked out from; not for aesthetic reasons but practical ones, the locales affording natural hunting blinds. In conclusion he argued that whilst a piecemeal spread of scattered farmsteads with associated small field systems had developed by the early to middle Bronze Age, Exmoor was 'marginal and peripheral to the social mainstream of events, beliefs and values' with a dominant hunterfisher-gatherer lifestyle persisting well into the Bronze Age (ibid, 346).

Based as it is upon a close and nuanced reading of the morphology of the settings and landscape context there is much of value in Tilley's interpretation. Its key strengths are threefold. First, is the way in which it extracts the settings from an otherwise familiar set of monumental structures - circles, rows, standing stones, cairns - that together constitute a familiar 'package' of megalithic architectures. Second, is the emphasis that is placed upon dynamism and continual re-working with the strong sense that the form visible today is merely a snapshot of a status that was potentially much more dynamic and fluid in the past. Third, is the importance that is placed upon animals - in this case red deer - in seeking to account for the settings. As will be seen, the agency of animals plays a central role in the alternative explanation tendered below, albeit articulating a very different set of people-stoneanimal relationships. Despite this, there are a number of limitations with Tilley's account. These derive in part from its practical reliance upon surface observation alone and the interpretative premium that is placed upon acts of looking and seeing in the past ${ }^{1}$. These are further compounded by a nagging sense that the prehistoric Exmoor being portrayed isolation, conservatism, hunting - owes as much to the present as it does the archaeological traces of the past. 


\section{The problem of visibility}

The fugitive character of the Exmoor settings makes them difficult to approach from a purely visual perspective as properties such as 'concealed' and 'hidden', whilst profoundly experiential, are locational attributes that have the unique property of being impossible to recognise, judge and evaluate from the location itself. As anyone who has tried to hide will know, a chosen location's degree of concealment can only be ascertained from every other location in the landscape. Experiential properties such as these offer a peculiar challenge to an embodied phenomenological methodology, particularly when you consider that if a location is truly hidden it will not be seen and recognised as such in the first place. It is to his credit that Tilley is able to evoke a strongly visual explanation for the location of the settings but, as will be argued here, perhaps visibility is the least relevant factor in this circumstance.

Key to understanding the visual relationship between the settings and broader landscape is a detailed understanding of the original environment within which they were erected and here we currently face two problems. The first concerns dating. We presently do not have any reliably dated stone settings; as a result their attribution to the period c.2200-1500BC is entirely a matter of conjecture. This leads directly on to the second issue. If the vegetation cover had remained relatively constant during this period then this may not fatally undermine any visibility argument being tendered. That it did not is suggested by palaeoenvironmental evidence. At present we have a broad, regional reconstruction based upon the analysis of upland peat deposits from Hoar moor. This argues for open woodland throughout the Neolithic, with possible evidence for browsing by domesticates in the early part of the sequence. At $c .1640 \mathrm{BC}$ there is a notable transition, with a reduction in tree pollen and an increase in grasses and plantains indicating clearance. A reduction in the frequency of Cinquefoil pollen at the very end of the Bronze Age suggests a reduction in grazing at this point (Francis and Slater 1990). At present there are a lack of detailed, local and extra-local palaeoenvironmental reconstructions in the immediate vicinity of individual settings or clusters of such, that can be deployed in order to interrogate and finesse this generalised regional picture. That finer-grained reconstructions can supplement this basic scenario is evident from emerging work that is being carried out on peat samples taken from mire sites less than a kilometre apart and close to the white ladder stone row (Comerslade) and Setta group of early Bronze Age round barrows (North Twitchen Springs), some $7.5 \mathrm{~km}$ to the southwest of the Lanacombe settings (Fyfe 2012). In each case the resultant pollen diagrams 
reflect the immediate local and extra-local environment of the mire. In summary, the results suggest that the early Bronze Age landscape here was semi-open, with notable levels of woodland present, particularly in the vicinity of the stone row. The conclusion drawn was that the round barrows were constructed in a more open zone in an otherwise intermittently wooded landscape than the diminutive stones of the white ladder row. From $1500 \mathrm{cal}$ BC the woodland around the stone row decreased with a concomitant expansion of grassland. This suggests intensification although there is no obvious archaeological surface trace of either an adjacent field system or settlement; a point I will return to later. At the same time the area around the barrows sees the grass replaced by heathland, which implies abandonment or a lowering in grazing intensity. By the end of the Bronze Age the intensity of land use in the vicinity of the stone row decreases with an increase in Bracken (ibid, 2768-72). These results argue strongly that there may have been considerable localised variation within the broader regional pattern, and further that specific monument types may have been preferentially constructed in areas of the landscape that were distinctive, both in terms of their vegetation and subsequent usage. This has important implications for any approach seeking to explore factors such as visual field (Tilley 2010, Table 7.3) or otherwise privilege the acts of looking and seeing. If the settings do date to the end of the Neolithic and beginning of the Bronze Age and, like the white ladder stone row, may have been deliberately placed in more wooded areas of a partially open landscape then any assumption of uninterrupted views is difficult to sustain. If in fact the settings are later, then we have to consider that they were constructed in areas showing evidence for more intensive land-use; socially much busier and less likely to have attracted either isolated hunting parties or the game they stalked.

To further explore the question of visibility, a series of affordance-based analyses were carried out on the landscape of Lanacombe with the express aim of interrogating the assumption of hiding and surveillance inherent in the hunting interpretation ${ }^{2}$. These were carried out as bare-earth visibility studies (reflecting a landscape as open as it is today) on the assumption that the effects of vegetation need only be considered if a possible/potential visual relationship existed in the first place for them to confound. For detailed discussion of the general methodology involved in generating affordance viewsheds and the theoretical assumptions that underpin them see Gillings $(2009$; 2012). Whilst the results confirm the observation that the settings avoid those parts of the landscape that afford the most panoramic and extensive views (Figure 2), there is little evidence that they were placed so as to maximise views of the coombe bottoms either. This is clear from Figure 3 which displays the 
results of a visual affordance analysis summarising those areas which afford the most extensive views of coombe bottom locations. In practice the coombe bottoms were identified and extracted from a 10m resolution digital elevation model of the Lanacombe study area using a combination of geomorphometric measurements (slope and curvature) (Olaya 2009). Views to and from each of the component $10 \mathrm{~m}$ cells making up the coombe bottom zone were then generated and summed. The resultant maps (looking-from and looking-to) also permitted investigation of the idea of covert observation through simple GIS-based map algebra, extracting one from the other to flag those areas of the landscape which afford good views of the coombe bottoms whilst being largely out of view themselves - precisely the qualities one would expect for a hunting blind (Figure 4). Whilst such locations do exist in the study area the settings do not appear to be located in them. To complement this the general visual exposure of each area of the landscape was investigated through a global affordance analysis, where the assumption is that identifiably hidden or covert locations would be visually unobtrusive. This was supplemented by a hiddenness index (ie a global measurement of hiddenness independent of any particular location) where each component $10 \mathrm{~m}$ cell making up the landscape terrain model was quantified according to how deeply hidden it was from every other conceivable viewpoint ${ }^{3}$. Once again there is nothing to suggest that the diminutive monuments occupied covert or hidden areas of the. If the general visual properties of the setting locations are underwhelming, what about the claims of preferred directionality? As noted by Tilley, the locational preference of settings for gentle slopes results in an inherent directionality to their fields-of-view insofar as the overall viewshed is inevitably curtailed in the upslope direction. This is confirmed in Figure 5 where the outer boundaries of the bare-earth viewsheds are mapped alongside horizon profiles; in each case these have been generated from the highest and lowest component stones of the setting. Whilst the views are undoubtedly directional, the key question here is the old chestnut of assumed causality - is the directionally constrained character of the view the raison d'etre or merely an unavoidable consequence?

Taken as a whole, the results of the global visibility analyses suggest that in visual terms the locations occupied by the settings are in no way distinctive or special. Perhaps more importantly, if covert observation was a prime factor in the placement of the settings then there were much more suitable locations within which to raise them. This would certainly apply to the more open landscape of the middle to late Bronze Age if the settings were erected at this time. In addition, and as will be discussed below, whilst the landscape during 
this period may have afforded more extensive views it is increasingly unlikely to have been as culturally empty as the hunting interpretation supposes. If instead they were raised during the later Neolithic-early Bronze Age we need to consider the vegetation factor and possibility that the settings were erected in patchy woodland, perhaps deliberately in areas that were more densely wooded or not so intensively cleared. This brings into question the assumption that the settings ever occupied vantage points that offered vistas of the kind implied by Tilley.

\section{The problem of geometric form and commonality of purpose:}

Whilst stone settings are extricated from a generalised late-Neolithic to early Bronze Age suite of ritual monuments in Tilley's account, the insistence upon a geometric form implies a degree of coherence within the group itself; adherence to a rigidly formal layout implying commonality of purpose. An assumption of geometric regularity can also result in a tendency to assume (and project) such when the reality may be less clear cut. This is perhaps exemplified by Chanter and Worth's original survey records which are dominated not by the component stones themselves but instead the parallelograms, axes and triangles drawn in to link them (Figure 6). It is perhaps as much this idiosyncratic mode of representation as the ground reality that led to subsequent claims that Exmoor's stone settings resemble a series of Euclidean exercises (eg Burl 1993, 89). The extent to which the assumption of geometric form has become embedded is evident in Tilley's claim that a 'concern with geometry and precise arrangements and alignments of these stones is quite clear in those cases where the original arrangements have been well preserved' (2010, 308 emphasis added). The implication is that non-geometric form is a consequence of taphonomy and nothing else.

The argument I would like to present here is that whilst geometric-form has become something of a leitmotif, not all of the settings take such forms and subsequent alterations and modifications need not have adhered to (or been guided by) the same formal criteria. Even within the sample of 15 settings discussed by Tilley there are a number where regularity of form is difficult to sustain. The results of geophysical survey and small-scale excavation have highlighted two important factors that are not evident from surface remains alone. First is the sheer variety of the practices used to raise and fix the component stones of individual settings. Some of these appear to have been rapid and expedient, others more structured; some stones seem to have been deliberately intended to be repeatedly raised and lowered, with stones found both upright in closely-fitting, sleeve-like cists of upright slabs and other lying neatly alongside such sockets (into which they could easily and effectively be inserted). 
Others were fixed permanently in place. The end result is more a collection than a coherent whole; a composite or medley of individual stones raised by different people at different times. For example, excavation on three of the stones making up the setting of Lanacombe I revealed evidence for three very different strategies and practices for fixing them in place (for summary see Gillings in press). Second, they have also stressed how unrepresentative the surviving ground plan is with respect to now lost or de-commissioned stones; this applies to both non-geometric and geometric forms. Take for example the setting at Tom's Hill where geophysical survey enabled erosion hollows (proxies for former stone positions) to be disentangled from mortar craters (the site was located on a military target range) the resultant picture disrupting what had been until that point interpreted as a straightforward geometrical form comprising three parallel rows (Gillings et al. 2010). More complex is the setting of Furzehill Common I. The RCHME plan of the site depicts the surviving remains of a typically geometric setting taking the form of stones (standing and fallen) alongside animal erosion hollows taken as proxies for former stones (Figure 7). One of the stones (stone D) just protruded above the turf and was included despite uncertainties on the part of the surveyors who noted the presence of many other such 'just protruding' stones that were excluded from their plan. It is tempting here to see the inclusion of D solely on the grounds of it forming an expected right-angle with respect to stones $\mathrm{E}$ and $\mathrm{B}$. When an excavation was carried out at the site in 2011 as part of the National Park Authority's on-going monument consolidation programme there was no surface trace of stone D or the other protruding stones noted by the surveyors. When excavated, stone D proved to be a de-commissioned standing stone that had been lifted from a carefully constructed collar of supporting orthostats and deliberately lain next to its stonehole. If $\mathrm{D}$ then what of the other stones excluded from the plan? The results of geophysical survey further complicated the picture, with the stone D arrangement generating a distinctive soil resistance signature shared with positions $\mathrm{F}$ and $\mathrm{C}$ and two unmarked locations some 12 or so metres to the east (one sitting on the very edge of a dispersed cairn) forming a rectangle with $\mathrm{F}$ and $\mathrm{C}$ (Figure 7). The implication here is of a markedly geometric form whose stones were erected using the same basic approach, yet not the geometric form recorded by the RCHME and one whose component stones were designed to raised and lowered. As for stones $\mathrm{E}$ and $\mathrm{B}$, the only ones standing today, they sit awkwardly within this pattern and if we can read the geophysical survey result as indicative of how the stones were fixed in place, employed a very different technology for raising them (Gillings and Taylor 2011b). 
In the case of Lanacombe we have a cluster of five settings (Figure 8). Two of these (Lanacombe I and II) are difficult to see in geometric terms, comprising loose, linear scatters of upright stones. Lanacombe III and the new Trout Hill setting are described as flattened parallelograms with outliers, the latter stones so described because they do not comfortably fit into the assumed geometric archetype. If instead these 'outliers' are seen as integral components the settings are much less convincingly geometric. The visible stones at Lanacombe IV certainly seems to form a triangle, but only if three other potential uprights noted by Quinnell and Dunn (elements fallen and/or partially covered) are excluded (1992). If we were to take Tilley's suggestion that the layout of the stones reflects that of a formal hunting party then these sites appear more like loose gatherings or skirmish lines than carefully structured co-operative groupings.

In conclusion, whilst some Exmoor settings may indeed have been rigidly geometric many were clearly not, and insisting upon geometrical regularity may influence how and what we record as component stones. Rather than seeing a single, coherent class of structure we may instead be seeing a range of very different imperatives - some widespread, some highly localised - being played out through a shared and flexible material expression, the raising upright of clusters of small stones (Gillings in press). Whilst it may make sense to separate some of the settings from the more familiar suite of stone rows, circles, cairns and standing stones, some of the latter are themselves notable for the highly geometric forms they embody (Porlock circle is a near perfect circle (Gray 1928); the small cairns excavated on Lanacombe are elliptical in plan and aligned on a shared long axis (Gillings 2013); and the now lost Maddocks Down stone row appears to have displayed remarkable levels of regularity and symmetry (Chanter and Worth 1905). This could be read either as settings serving similar roles to those monuments or that concerns with geometry, like the use of small upright stones, were part of a small and distinctive set of material practices unique to Exmoor that were drawn upon in a host of ways. Whilst Tilley is undoubtedly correct to stress the continual reworking and gradual emergence of the settings this need not be taken as reflecting more of the same; one geometric form replacing another. If anything the evidence from geophysical survey and excavation points towards a much more complex picture hinting at a very dynamic and active process of re-interpretation and negotiation. As a result any one-size fits all explanation should be questioned, with individual settings and groups of such sites potentially enfolding long and complex biographies. 


\section{Problems with the assumption of backwardness:}

As highlighted by Riley and North, the settings are more ubiquitous than other prehistoric site types on Exmoor and are frequently found in close association with small cairns, boundaries and settlement remains (2001, 31). The particular problem with Exmoor is that unlike the granitic uplands of Dartmoor and Bodmin, such settlement traces are extremely subtle and fragmentary, leaving little in the way of discernable surface traces of the kind detectable by traditional surface survey (whether quantitative or phenomenological). Take for example Lanacombe and what we now know of the landscape context of the settings. Far from sitting in splendid isolation, geophysical survey and excavation at Lanacombe II and III has revealed that the stones were associated with a series of fragmentary linear boundaries incorporating carefully aligned and linked cairns (whose arrangement was reminiscent of the fragments of co-axial field system recorded at Codsend Moor some $9 \mathrm{~km}$ to the west) and a circular postbuilt structure (Gillings et al. 2010; Gillings 2013). Needless to say, only the cairns had left any surface signature. As already noted, fine-grained palaeoenvironmental reconstruction to the southwest of Lanacombe has identified appreciable Bronze Age landscape modifications that have likewise left no visible field system or settlement traces of the type likely to be picked up by field survey. Any explanation that stresses the isolation of the setting locations therefore runs the risk of projecting their current status into the past. Rather than a cultural backwater we need to start placing the settings in much busier landscapes; a situation sagely predicted by Riley and Wilson-North $(2001,24)$.

\section{So what were they for?}

In an attempt to build constructively on this critique attention is now turned to the cluster of settings at Lanacombe. The first point to raise, building directly upon the discussion above, is that the interpretation tendered here relates solely to this group of settings and the relationships that exist between them. Whilst it may well have broader utility this is something that must be demonstrated rather than assumed. So what, if anything, does make the locations significant and how might we begin to make sense of the Lanacombe settings? The lack of any unusual visibility properties has already been discussed. In general topographic terms the locations of the settings also appear on the surface to be remarkably anodyne. Unlike the remainder of the Lanacombe spur they are found in a much gentler area of slope lacking any crisp line of flexure between the plateau and coombe edge that might be considered a liminal or bridging zone between the visually exclusive worlds of deeply incised coombe bottom and essentially flat plateau top. Where the setting locations are distinctive is 
not on the surface but beneath it. Geophysical survey across blocks of open moorland between the stones has identified an exclusive correlation between setting locations and bands of raised soil resistance corresponding to zones of more shallow buried bedrock. Running perpendicular to the contour the stony character of these bands is reflected in the vegetation patterns observable today, supporting much shorter grass and rushes in contrast to the wide swathes of purple moor grass in between (Gillings et al. 2010) (Figure11). Put simply, these are zones that are much clearer of vegetation; they are also generally drier, Lanacombe I in particular an area where cattle like to congregate and gather ${ }^{4}$.

Looking to the settings themselves, as has been noted it is difficult to argue for any geometric regularity and this lack of pattern is repeated in terms of the placement of the component stones (Figure 9). Instead we have scattered strings of small stones running across the contour. However, if we take the settings as a group a pattern is discernable. Like steps on a staircase seen side-on, Lanacombe I to III drop progressively lower down the hillside linking the top of the plateau to the top of the slope immediately above the coombe and the stream that flows within it (Figure 10). Following the stones and contour offers a gentle route down from the plateau top to the coombe bottom (and vice versa). Opposite Lanacombe III on the far side of the Coombe the new Trout Hill setting sits above a gently sloping route up and on to Trout Hill just to the North of a small side-valley. Lanacombe IV likewise sits above a modern path down the tip of the Lanacombe spur.

\section{Movement and pause}

“Antell, of Whimb, Furzehill, asserted that the stones were used as marks to which to gather the sheep, or that some of them were so used, and gave the name of Farmer John Watts as the last to put them to this purpose on Furzehill Common" (Chanter and Worth 1905, 390).

The settings at Lanacombe seem to preferentially cluster within a series of linear zones marked by a distinctive vegetation texture in the sense proposed by John Evans (2003, 4572), zones that may well have offered more immediately traversable corridors through the landscape - clearer of dense undergrowth and drier. The possibility that standing stones may have served a vital navigational role has been discussed by Darvill, who noted how paired standing stones in particular 'seem to mark boundaries between contrasting environments: a 
terrace edge overlooking a valley floor, or a hilltop where the land changes gradient. As such they might well have formed symbolic doorways or gateways in the landscape, structuring and directing movement while imparting purpose and meaning to those who passed by' (Darvill 2013, 149 see also Darvill 2010, 191-2 for similar sentiments). In the case of Lanacombe, the diminutive size and virtual invisibility of the structures make it difficult to think in terms of the stones themselves physically effecting navigation and the deliberate structuring and/or directing of movement that it implies. They are found on existing pathways rather than serving to define and instantiate them. So who and what may have they been for? To answer this we need look at a feature of the settings that has attracted much comment, but entirely in the context of management concerns and negative impacts. This is the fact that animals like them. Indeed, stock animals like them so much that over time their rubbing not only wears substantial hollows around the bases of the uprights, but eventually they knock them over, leading to the need for a proactive programme of ongoing management and restoration (as well as remedial excavation work of the kind that informs the current discussion). If they attract the attention of animals today we can assume that they always did, and that far from a modern management issue, the progressive toppling of stones (and their subsequent re-setting) has been an on-going process for as long as animals have been grazing the open moor.

In an earlier discussion the possibility was raised that the settings may have served a framing role, active devices for structuring and orchestrating arrangements within and between participants and the landscape. This was illustrated by drawing analogy to the early Iron Age Khirigsuurs of the Mongolian steppe (small mounds and associated stone settings), which were linked directly to nomadic pastoralism serving as stages for activity and sighting points (Gillings et al. 2010, 315). Here I would like to develop this argument further drawing inspiration from ethnographic and archaeological research carried out on historic Inuit caribou hunting landscapes in Harvaqtuuq region of Nunavut Territory, Canada. Here Stewart et al. noted the presence at camp sites of hunting blinds and small standing stones termed inuksuit (Stewart et al. 2004, 188; fig 4) amongst other structures, bone and artefact spreads (p.188). Of particular interest here are the inuksuit which serve as markers acting "in the capacity of a human" in a wide variety of capacities linked to different tasks, roles and relationships in different, distinct areas of the landscape (Hallendy 1994 cited in Stewart et al. 2004, 198). For example, lines of such stones are found on the northern side of the river, the area least modified through human activity, and served to guide the Caribou; "stones that 
have a "natural" function - one of communicating direction to animals" (ibid, 203). In this case rather than serving a metaphoric or symbolic purpose the stones are active, folded into a complex set of relations between people, animals and landscape; endowed with person-like abilities and exerting a tangible power in relation to the caribou. At this point it is important to stress that this is not an attempt to replace a markedly interpretative approach with a mundane functional one; something strongly metaphorical - the social organisation of the hunting party, the spread of antlers, with something prosaic - road signs. Rather than metaphors signalling and materialising the importance of place, the settings were instead active agents in a fluid world of human and animal movement between plateau tops and coombe bottoms.

The stone settings of Lanacombe may not have been exclusively about people at all, instead bound up in a complex animal landscape of which people were merely one element. Erected for, or on behalf of, the animals, or perhaps - following this line of argument to its logical conclusion - even by them (albeit with the assistance of the people who accompanied their journeys or watched them depart and safely return). They were after all instrumental in knocking them down. This is to echo Kahn's work on the agency of small stones and their widely perceived ability to move (with the assistance of people co-opted into their world view) (1990). This would certainly explain the lack of any marked monumentalising tendency as there is little incentive to raise stones larger than required ${ }^{5}$. Nor do we need to invoke any miniaturisation hypothesis to account for their scale - they were not smaller examples of something else but instead precisely the size they needed to be. Having flagged the importance of animals in seeking to explain the Lanacombe settings the next key question is whether this was indeed bound up with hunting, as has been argued by Tilley, or more pastoral activities? Dating is a crucial issue. The tendency has been to place the settings in the later Neolithic-early Bronze Age, based entirely upon analogy with dated monument sequences form other parts of the British Isles, the settings regarded as a local manifestation of a widespread and varied phase of monument construction, particularly in upland areas (Bradley 2007, 172-5). This in turn relies upon the assumption that the settings are monuments. What if they are not? What if they are instead contemporary with the traces of landscape modification, settlement and field system evidence that are slowly beginning to emerge? The Lanacombe settings in particular appear to have been woven into a world of cairns, hedge lines, boundaries and occupation areas rather than isolated hunting locales and 
what dates we do have for these latter features suggest they belong to the early-middle Bronze Age (Gillings 2013) ${ }^{6}$.

As for what particular animals or the scale of animal herding and exploitation, the paucity of excavated sites on the moor coupled with lack of preservation of animal bone in the acidic soils means that at best we can only speculate. Accepting the inherent circularity of the argument, the scale of the upright stones would seem better suited to sheep than cattle. Although cattle have been argued to have been the principal grazing animal on Exmoor during the middle to late Bronze Age when we begin to see the emergence of fields and visible settlement sites on the moor (Riley 2009) the importance of sheep on the moor throughout the $2^{\text {nd }}$ millennium should not be underestimated. Although we have no direct evidence for sheep from Exmoor in the early to middle Bronze we have indirect evidence in the form of possible loom-weights at Holworthy (Green 2009, 55; 58; 74) though their identification as such is far from conclusive. Excavations at the coastal site of Brean Down on the edge of the Somerset levels to the east of Exmoor have produced good assemblages of animal bone, with sheep rivalling cattle in terms of overall percentages (Bell 1990, 221-41) and sheep certainly dominated upland grazing on the moor in the early modern period. For example, 30,000 were recorded as grazing in Exmoor Forest (of which Lanacombe is part) in an audit of 1817 (Orwin and Sellick 1970, 45-6).

One crucial piece of information concerns the repeated discovery of stones that had been deliberately engineered in such a way as to permit them to be lowered (de-commissioned) and raised and the ubiquity of triggers. In the case of the latter we may once again have overlooked the obvious. Since the first detailed records of Chanter and Worth, the presence of excessively large packing stones - triggers - has been taken as a proxy for a former stone position where the original upright had been lost without any consideration of why they were so conspicuous in the first place. It will be argued here that trigger stones were an integral part of this cycle of raising and lowering stones, the triggers serving to facilitate the routine removal and replacement as well as marking the stonehole during periods when a given stone was recumbent. This in turn implies a very dynamic picture and one that points to a need to catch the attention of animals at certain times and not others. This could very well have been linked to the seasonal cycle; for example the spring moult for sheep. In this case the stones served less to guide the animals along prescribed route ways than encourage them to pause (and perhaps rub) at predetermined points along those familiar paths. Gathering places. 
Returning to the quote that headed this section, rather than an opportunist, Farmer John Watts may well have been continuing a tradition that had its origins in the Bronze Age.

\section{Conclusions}

It has been argued here that far from serving as metaphorical representations of hunting groups, the Lanacombe settings served to engineer moments of pause and gathering for flocks and herds along distinctively textured routes between the plateaus and stream valleys that bisect them. Whilst the routes themselves were permanent, marked out by changes in openness and vegetation, the standing stones were not required on a year-round basis - less timeless monuments than a deliberately flexible architecture deployed on a much more contingent basis as and when required. With 59 settings recorded to date and with new examples regularly coming to light, the challenge is to move away from seeing them as a unique class of megalithic monument and instead to begin to break this down and identify the different rationales that gave rise to these structures. The argument presented here is that whilst some may well have formed an integral part of wider ritual-symbolic landscapes incorporating circles, rows and cairns and others may well have served as metaphorical representations of hunting parties, those on Lanacombe at least were woven into a complex animal landscape of movement and pause. Erected not so much for animals as with them. Rather than impoverished, marginal or peripheral in comparison to the granitic uplands of Dartmoor and Bodmin, Exmoor's surviving prehistoric archaeology is once again proving itself to be merely different, and none the less interesting for that. In his discussion of the settings Grinsell noted that they might 'provide a key to an uncharted aspect of the archaeology of the region' $(1970,47)$ and I would argue that in this case he was absolutely right. Rather than the highly visible traces of what we might think of as fixed locations and structures - settlements and field boundaries - we have instead a snapshot of those transient elements of the upland landscape that are usually on-the-move. These are elements that are invisible to field survey or inferred on the basis of assumed nodal destinations. The possibility the Exmoor settings raise to explore and reconstruct movement on a landscape scale is therefore highly significant.

There are two main conclusions to be drawn from the foregoing discussion. First is that whilst much effort has been expended in stressing their uniqueness as a class of structure, such uniqueness has been downplayed when looking within this group. Here there has been a tendency to emphasise broadly shared morphological characteristics (such as a rigidly 
geometric form) that in turn implies commonality of purpose. It is argued here (see also Gillings in press) that we may instead be seeing very different imperatives being worked through using a limited range of material motifs involving the deployment of small standing stones. As a result we should not seek a single over-arching explanation to account for these structures and in this vein an interpretation has been tendered for the group of settings encountered on Lanacombe, arguing that in this specific case the group of stone settings might be interpreted as gathering points (places of pause) on animal pathways through the moorland landscape. Second, far from a cultural backwater throughout the $2^{\text {nd }}$ millennium, traversed by essentially hunter-gatherer groups moving between metaphorically potent hunting blinds marked by symbolically patterned scatters of stones, the settings may have been part of a much more dynamic and busy landscape of settlements and boundaries, albeit one that has little in the way of surface signature and has thus been elided from accounts based upon field survey and phenomenology alike.

\section{Acknowledgements}

The interpretations presented here draw directly from fieldwork supported by the Exmoor National Park Authority (ENPA), British Academy, Society of Antiquaries and the Prehistoric Society. Thanks are due to Rob Wilson-North (ENPA), Jessica Turner (Northumberland National Park Authority), Jeremy Taylor (University of Leicester) and Josh Pollard (University of Southampton) for their unflagging support. The drafts of this paper have benefitted greatly from constructive, yet critical feedback, by Jeremy Taylor and two anonymous referees; needless to say any errors and omissions are entirely the fault of the author.

\section{Endnotes}

1. Arguably an unavoidable legacy of exclusively phenomenological field craft.

2. Affordances are emergent, profoundly relational properties that arise in response to the abilities of animals (including people) and situational features of an animal-environment (see Gillings 2012). The concept is in many ways equivalent to the notion of relational-capacities central to DeLanda's influential work on assemblage theory $(2013,66-67)$.

3. Whereas traditional GIS-based viewshed analysis studies the views generated by single view-points or small groups of such, the methods employed here work on the basis of generating and combining viewsheds for all possible viewpoints in a given landscape (see Gillings 2009). This enables global patterns of visibility to be generated through maps that encode changing patterns of either how much a given location can see or the area from which it can be seen. These in turn offer new, and frequently stimulating heuristics. As noted in the text, 
the current study also employed an innovative technique for generating a global hiddenness map. This took the same approach as the above insofar as the focus was upon all possible viewpoints in the study area, but instead of calculating areas in view, it identified all locations out of view and assigned each a value equivalent to its depth (in metres) below the sight-line; ie how deeply it was hidden. By combining the results of all of the individual viewpoints (over 70,000 in this case) a single map encoding global (ie location-independent) hiddenness was generated. A research paper discussing the methodologies in detail is currently in preparation (entitled Mapping invisibility: GIS approaches to the analysis of hiding and seclusion).

4. An observation confirmed by the local stockman. He also noted that Lanacombe I had been a popular location for generations of local shepherds and stock men to have their ashes scattered.

5. In this regard it is interesting to note William's comment about the early modern practice in Wales of erecting cattle rubbing stones in the centres of fields (typically $1.5 \mathrm{~m}$ in height). Interestingly, here a marked monumentalising tendency did emerge as farmers sought to out-compete each other through the size of such stones (Williams 1988, 14). That larger stones were available on Exmoor is clear from the presence of standing stones some 2 -3m in height (Grinsell 1970, 47-8).

6. Although we currently have no evidence, it is quite possible that pastoral activities were taking place on Exmoor much earlier. 


\section{Bibliography}

Bell, M. 1990. Brean Down excavations 1983-1987. London: English Heritage.

Bernardini, W., Barnash, A., Kumler, M. and Wong, M. 2013. Quantifying visual prominence in social landscapes. Journal of Archaeological Science 40(11), 3946-54.

Bradley, R. 2007. The Prehistory of Britain and Ireland. Cambridge: Cambridge University Press.

Burl, A. 1993. From Carnac to Callanish: the Prehistoric Stone Rows and Avenues of Britain, Ireland and Brittany. Yale: Yale University Press.

Chanter, J.F. and Worth, R.H. 1905. The rude stone monuments of Exmoor and its borders. Reports \& Transactions of the Devonshire Association 37, 375-97.

Darvill, T. 2010. Prehistoric Britain. London: Routledge.

Darvill, T. 2013. Monuments and Monumentality in Bronze Age Europe. In H. Fokkens and A. Harding (eds) The Oxford Handbook of the European Bronze Age, 140-58. Oxford: Oxford University Press.

DeLanda, M. 2013. Intensive Science and Virtual Philosophy. London: Bloomsbury.

Evans, J. 2003. Environmental Archaeology and the Social Order. London: Routledge.

Francis, P.D. and Slater, D.S. 1990. A Record of Vegetational and Land Use Change from Upland Peat Deposits on Exmoor. Part 2: Hoar Moor. Proceedings of the Somerset Archaeological and Natural History Society 134, 1-25.

Fyfe, R. M. 2012. Bronze Age landscape dynamics: spatially detailed pollen analysis from a ceremonial complex. Journal of Archaeological Science 39(8), 2764-73. 
Gillings, M. (in press). Betylmania? - Small standing stones and the megaliths of southwest Britain. Oxford Journal of Archaeology 34, 3.

Gillings, M. 2013. Excavation of the prehistoric landscapes of Lanacombe, Exmoor. Proceedings of the Somerset Archaeological and Natural History Society 156, 41-73.

Gillings, M. 2012. Landscape Phenomenology, GIS and the Role of Affordance. Journal of Archaeological Method and Theory 19(4), 601-11.

Gillings, M. 2009. Visual affordance, landscape and the megaliths of Alderney. Oxford Journal of Archaeology 28 (4), 335-56.

Gillings, M. and Taylor, J. 2011a. Excavation and survey at the Exmoor stone settings of Lanacombe I and IV. Proceedings of the Somerset Archaeological and Natural History Society 154, 23-34.

Gillings, M. and Taylor, J. 2011b. Geophysical Survey and Excavation at the Exmoor stone setting of Furzehill Common. Devon Archaeological Society Proceedings 69, 1-8.

Gillings, M., Pollard, J. and Taylor, J. 2010. The Miniliths of Exmoor. Proceedings of the Prehistoric Society 76, 297-318.

Gray, H. St. George, 1928. The Porlock Stone Circle, Exmoor. Proceedings of the Somerset Archaeological and Natural History Society 74, 71-77.

Green, T. 2009. Excavation of a Hillslope Enclosure at Holworthy Farm, Parracombe displaying Bronze Age and Iron Age Activity. Proceedings of the Devon Archaeological Society 67, 39-98.

Grinsell, L.V. 1970. The Archaeology of Exmoor. Newton Abbott: David \& Charles.

Kahn, M. 1990. Stone Faced Ancestors: the Spatial Anchoring of Myth in Wamira, Papua New Guinea. Ethnology 29, 51-66. 
Olaya, V. 2009. Basic Land-Surface Parameters. In T. Hengl and H.I. Reuter (eds). Geomorphometry: concepts, software, applications, 141-169. Amsterdam: Elsevier.

Orwin, C.S. and Sellick, R. 1970. The Reclamation of Exmoor Forest. Newton Abbot: David \& Charles.

Quinnell, N.V. \& Dunn, C.J. 1992. Lithic Monuments within the Exmoor National Park: a New Survey for Management Purposes. Unpublished RCHME Survey report.

Riley, H. 2007. Lithic Monuments on Exmoor: Some New Discoveries. The Warcome Water Stone Row and a Stone Setting on Trout Hill. English Heritage: Research Department Report Series no. 44-2007.

Riley, H. 2009. Hoar Moor and Codsend Moors, Exford and Cutcombe, Somerset, Exmoor National Park: Historic Landscape Analysis. English Heritage: Research Department Report Series 15-2009.

Riley, H. \& Wilson-North, R. 2001. The Field Archaeology of Exmoor. Swindon: English Heritage.

Stewart, A.M., Keith, D. and Scottie, J. 2004. Caribou Crossings and Cultural Meanings: Placing Traditional Knowledge and Archaeology in Context in an Inuit Landscape. Journal of Archaeological Method and Theory 11(2), 183-211.

Tilley, C. 2010. Interpreting Landscapes: geologies, topographies, identities (Explorations in Landscape Phenomenology 3). Walnut Creek: Left Coast Press.

Williams, G. 1988. The Standing Stones of Wales and South-West England. British Archaeological Reports British Series 197. Oxford: BAR. 


\section{List of Tables}

Table 1 - The Lanacombe settings. 


\section{List of Figures}

Figure 1 - Location of the monuments discussed in the text.

Figure 2 - An affordance viewshed encoding the extent of total view afforded by each location in the study area (for a discussion of the methodology behind this map see Gillings 2009).

Figure 3 - An affordance viewshed encoding the extent of coombe bottom visible form each location in the study area (left). This has been simplified to display just the upper quartile values (right); ie those locations affording the largest coombe views.

Figure 4 - The result of subtracting two affordance viewsheds: how visible each location is from the coombe bottom from how much of the coombe bottom it can see (left). This has been simplified to display just those potentially covert areas that see more than they are seen (right).

Figure 5 - Viewshed extents and horizon profiles determined for the upper and lowermost stones in each setting. The former demonstrate the inherent directionality; the latter the presence of a rising hillslope in the direction opposite that of the coombe bottom in each case. Uses tools developed (and kindly shared) by Wes Bernardini et al. (2013).

Figure 6 - An example of Chanter and Worth's unique style of presentation (Chanter and Worth 1905 Plate V).

Figure 7 - The results of the Furzehill Common fieldwork (simplified from Gillings and Taylor 2011b, fig 5).

Figure 8 - Plans of the Lanacombe monuments (after Quinnell and Dunn 1992; Riley 2007).

Figure 9 - Vertical profiles along the main axis of the Lanacombe monuments showing relative stone positions and heights. Open boxes indicate now fallen stones - the original height has been estimated by subtracting $0.1 \mathrm{~m}$ from the maximum dimension. The typical vegetation heights were measured in the field during late September. 
Figure 10 - The location of the settings, stepping progressively down the slope relative to the contours.

Figure 11 - The exclusive correlation between setting locations and the vegetation changes (darker) that at certain time of year mark the bands of shallower bedrock detected by geophysical survey (Gillings et al. 2010; Gillings 2013) (image extracted from Google Earth June 2014). 
Fugitive Monuments - Tables

\begin{tabular}{|c|c|c|c|c|}
\hline Site & $\begin{array}{l}\text { No. of } \\
\text { stones }\end{array}$ & Configuration & $\begin{array}{l}\text { Linear } \\
\text { extent }^{2}\end{array}$ & $\begin{array}{l}\text { Height } \\
\text { range }\end{array}$ \\
\hline Lanacombe I & $13(13)$ & $\begin{array}{l}\text { seemingly random } \\
\text { linear spread }\end{array}$ & $46.5 \mathrm{~m}$ & $\begin{array}{l}0.20- \\
0.85 \mathrm{~m}\end{array}$ \\
\hline Lanacombe II & $7(4)$ & $\begin{array}{l}\text { seemingly random } \\
\text { linear spread }\end{array}$ & $42.6 \mathrm{~m}$ & $\begin{array}{l}0.05- \\
0.56 \mathrm{~m}\end{array}$ \\
\hline Lanacombe III & $8(5)$ & $\begin{array}{l}\text { flattened parallelogram } \\
\text { with outliers }\end{array}$ & $43.3 \mathrm{~m}$ & $\begin{array}{l}0.11- \\
0.85 \mathrm{~m}\end{array}$ \\
\hline Lanacombe IV & $5(5)$ & triangle & $7.8 \mathrm{~m}$ & $\begin{array}{l}0.03- \\
0.65 \mathrm{~m}\end{array}$ \\
\hline Trout Hill & 5 & $\begin{array}{l}\text { flattened parallelogram } \\
\text { with outlier }\end{array}$ & $19.9 m$ & $\begin{array}{l}0.08- \\
0.32 \mathrm{~m}\end{array}$ \\
\hline \multicolumn{5}{|c|}{$\begin{array}{l}\text { 1. this reflects the number of stones currently visible (the number in brackets is } \\
\text { that recorded by the RCHME between } 1988-92 \text { (Quinnell and Dunn 1992). Note: } \\
\text { the new Trout Hill setting was only discovered in } 2005 \text {. } \\
\text { 2. Measured between the furthest components in each case }\end{array}$} \\
\hline \multicolumn{5}{|c|}{ Table 1 - key attributes of the stone settings discussed } \\
\hline
\end{tabular}




\section{Fugitive Monuments - Figures}
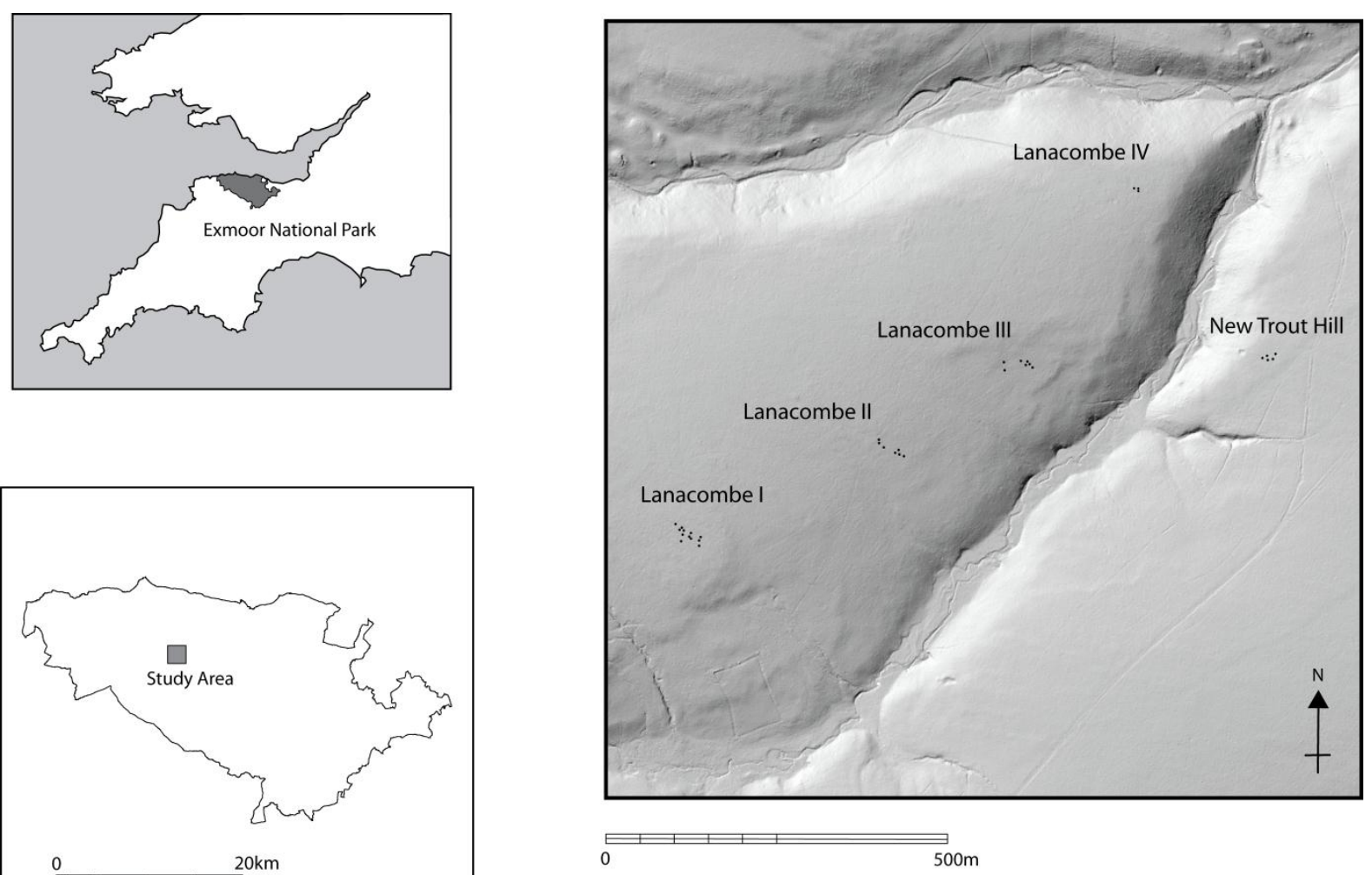

Figure 1-Location of the monuments discussed in the text. 

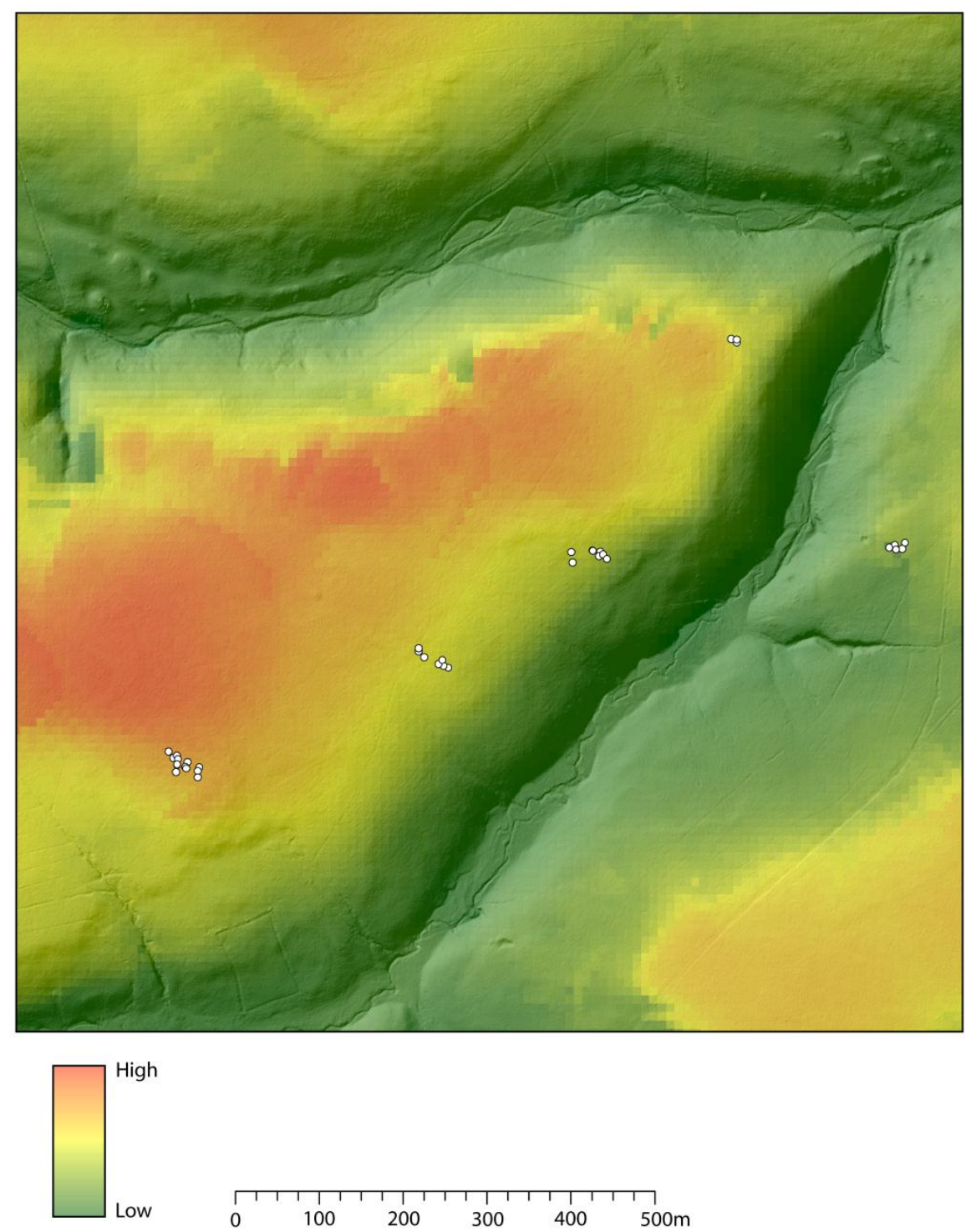

Figure 2 - An affordance viewshed encoding the extent of total view afforded by each location in the study area (for a discussion of the methodology behind this map see Gillings 2009). 

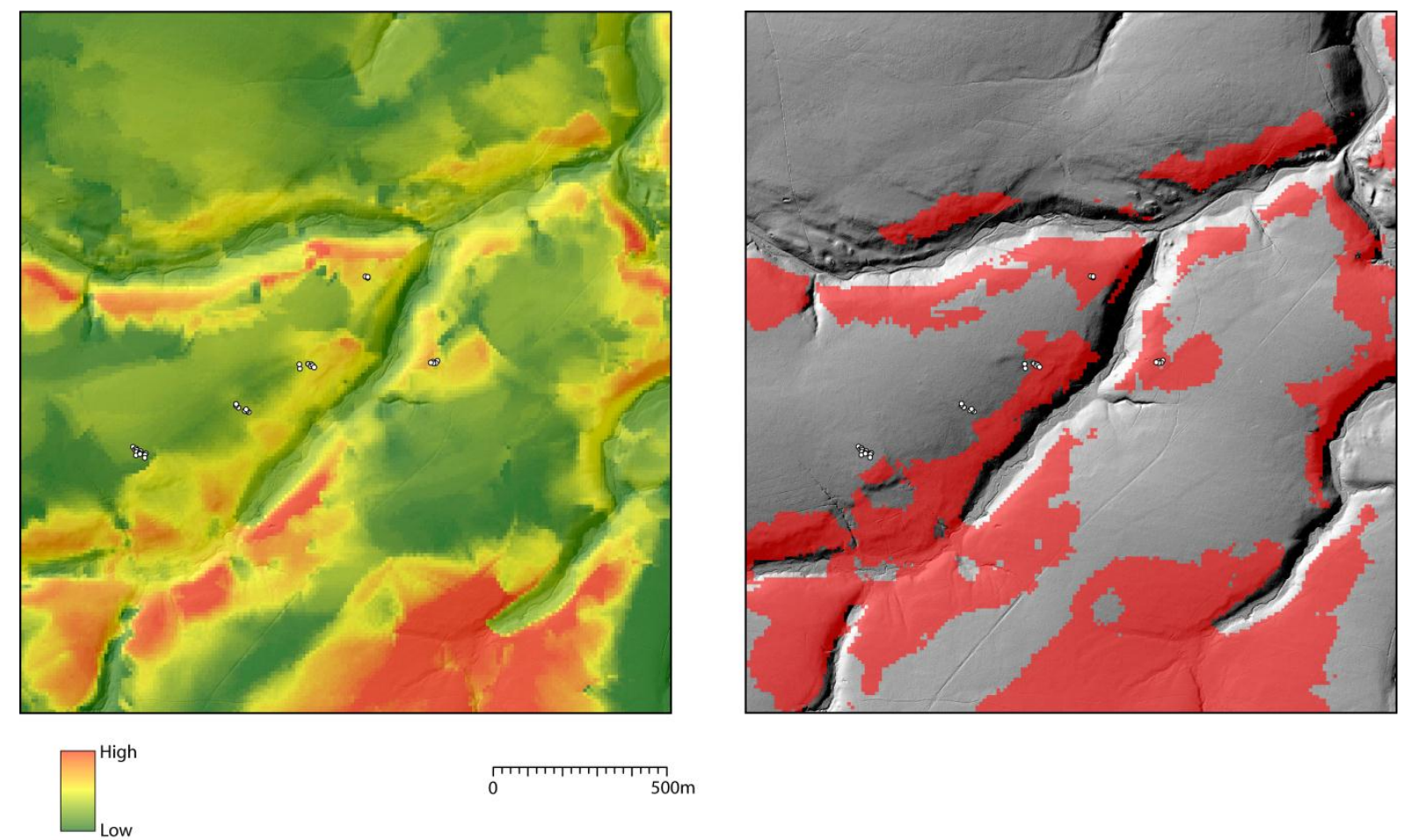

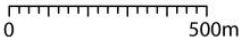

Figure 3-An affordance viewshed encoding the extent of coombe bottom visible form each location in the study area (left). This has been simplified to display just the upper quartile values (right); i.e. those locations affording the largest coombe views.
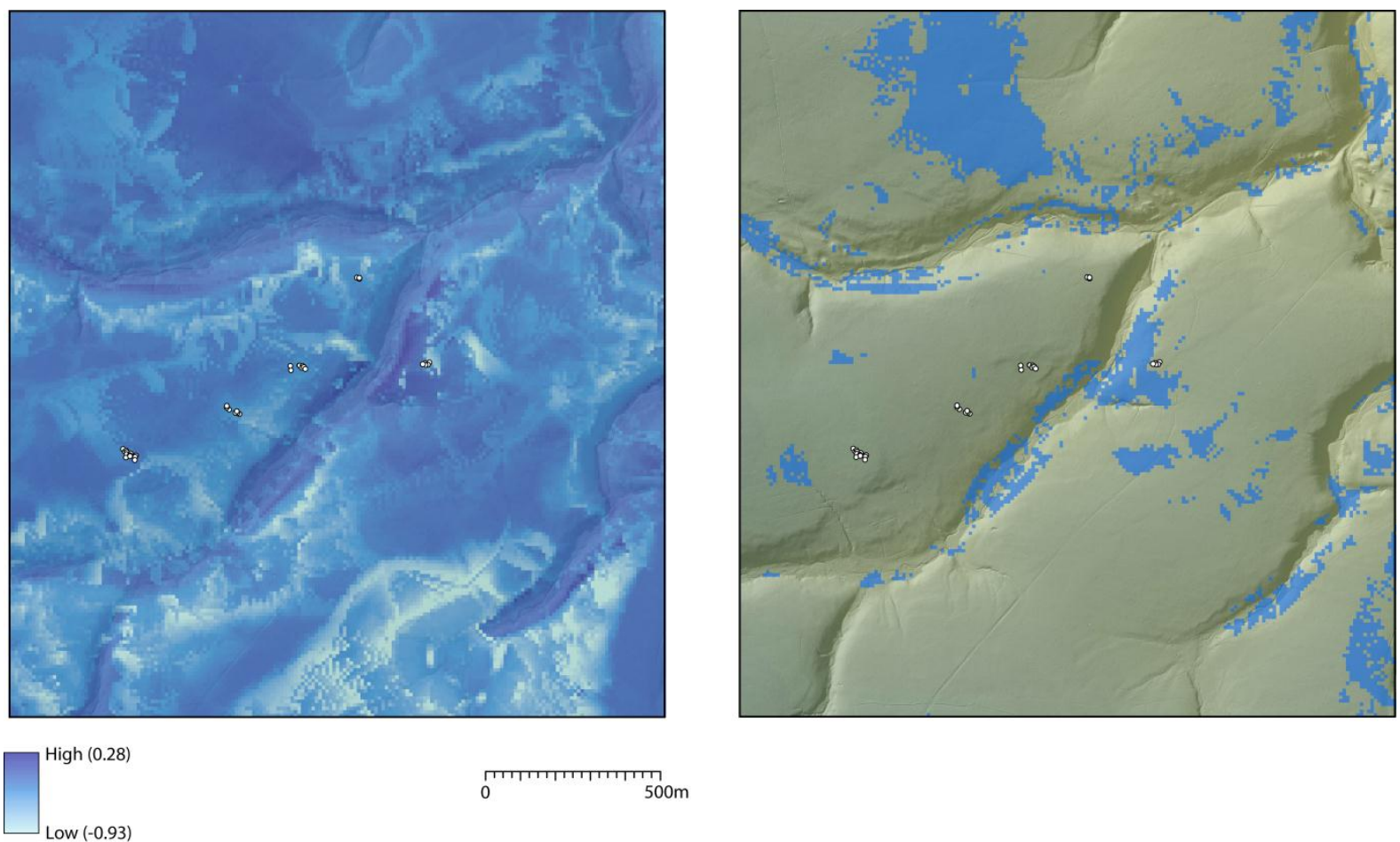

$00500 \mathrm{~m}$

Figure 4 - The result of subtracting two affordance viewsheds: how visible each location is from the coombe bottom from how much of the coombe bottom it can see (left). This has been simplified to display just those potentially covert areas that see more than they are seen (right). 

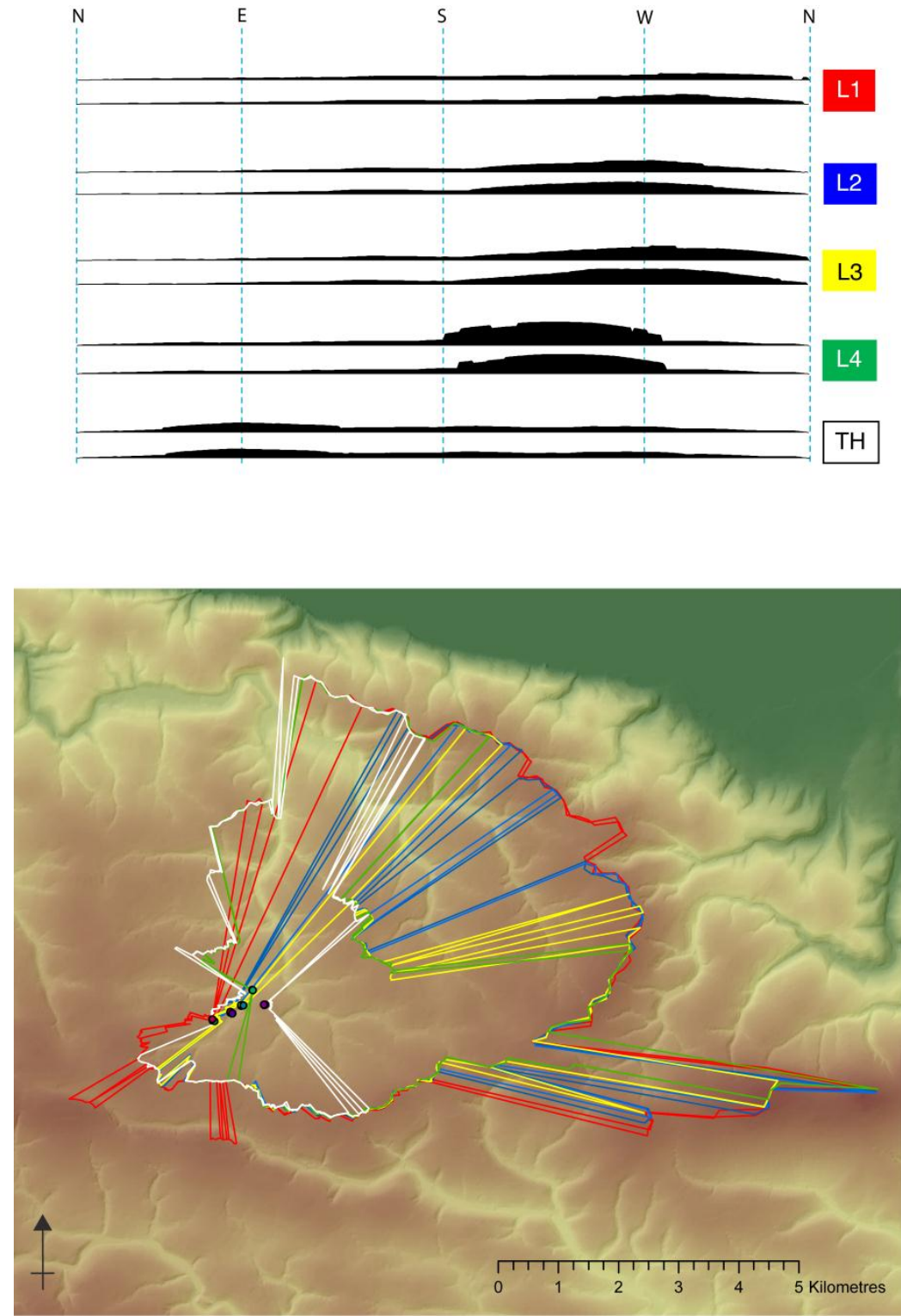

Figure 5 -Viewshed extents and horizon profiles determined for the upper and lowermost stones in each setting. The former demonstrate the inherent directionality; the latter the presence of a rising hillslope in the direction opposite that of the coombe bottom in each case. Uses tools developed (and kindly shared) by Bernardini et al. (2013). 


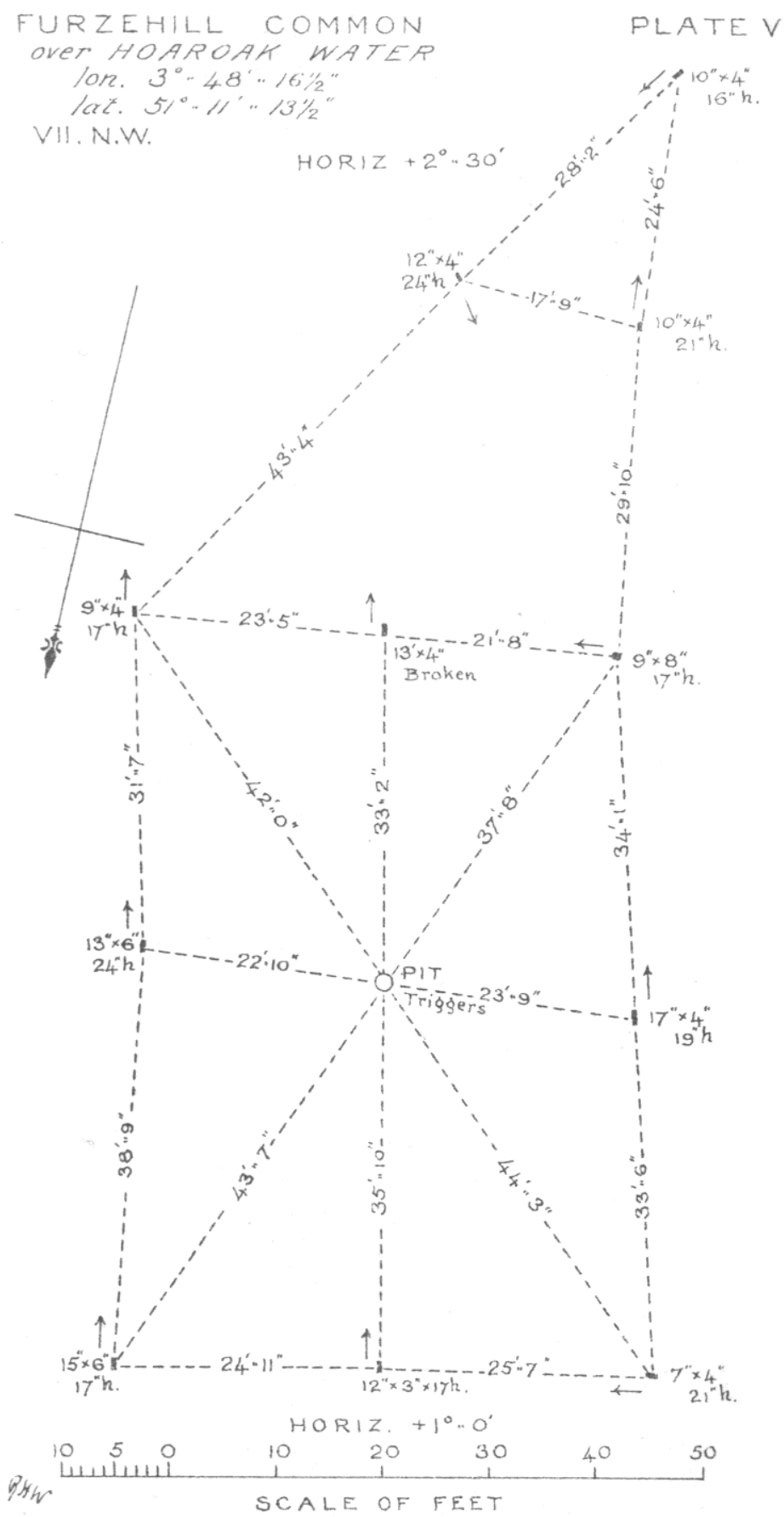

Figure 6 - An example of Chanter and Worth's unique style of presentation (Chanter and Worth 1905 Plate V). 

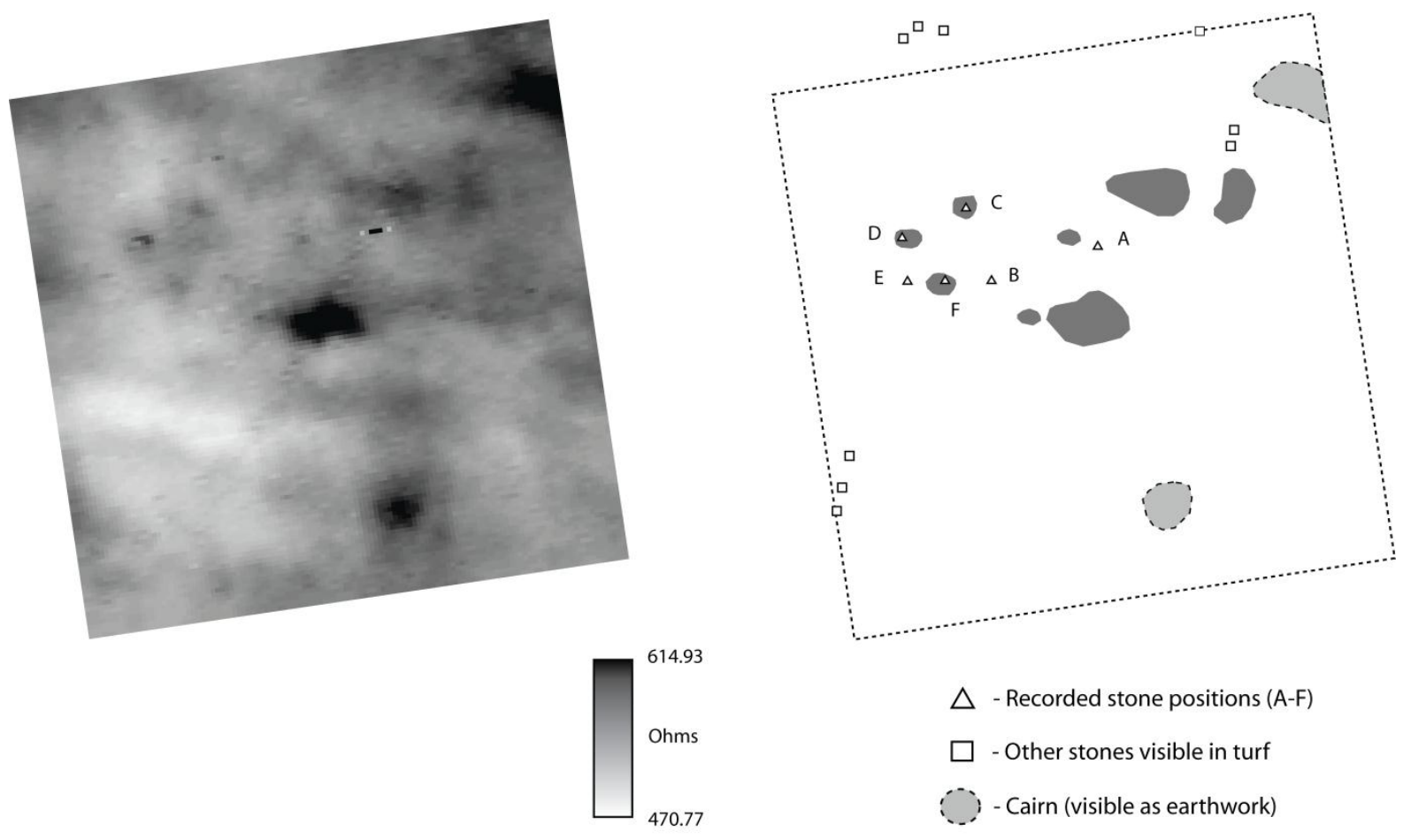
$\triangle$ - Recorded stone positions (A-F)
$\square$ - Other stones visible in turf
- Cairn (visible as earthwork)
- Dispersed cairns

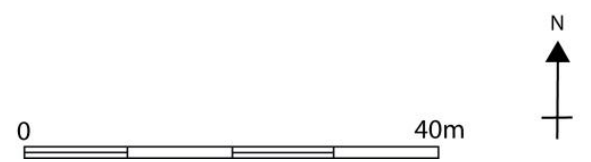

Figure 7- The results of the Furzehill Common fieldwork (simplified from Gillings and Taylor 2011b, fig 5). 


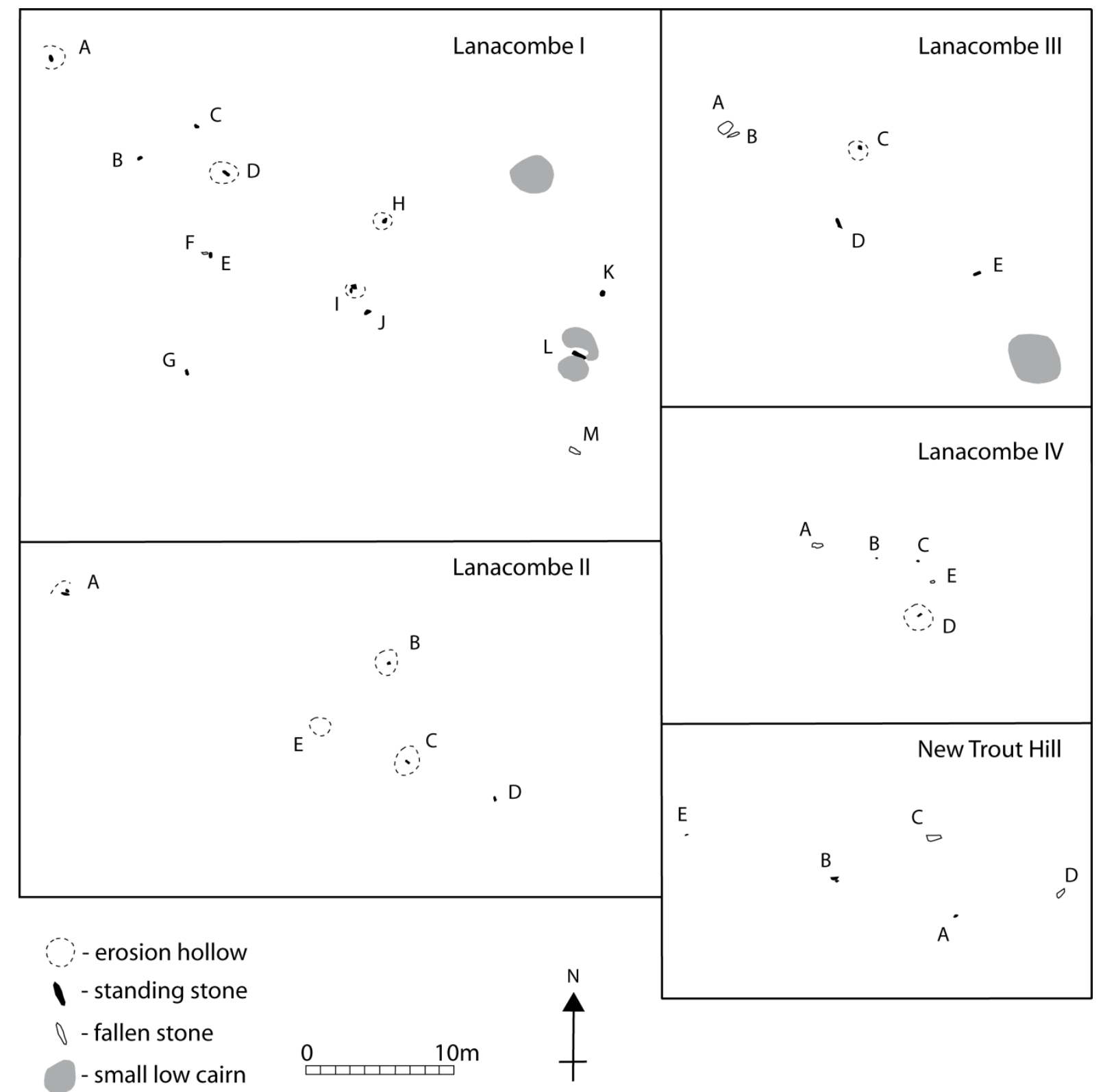

Figure 8 - Plans of the Lanacombe monuments (after Quinnell and Dunn 1992; Riley 2007). 

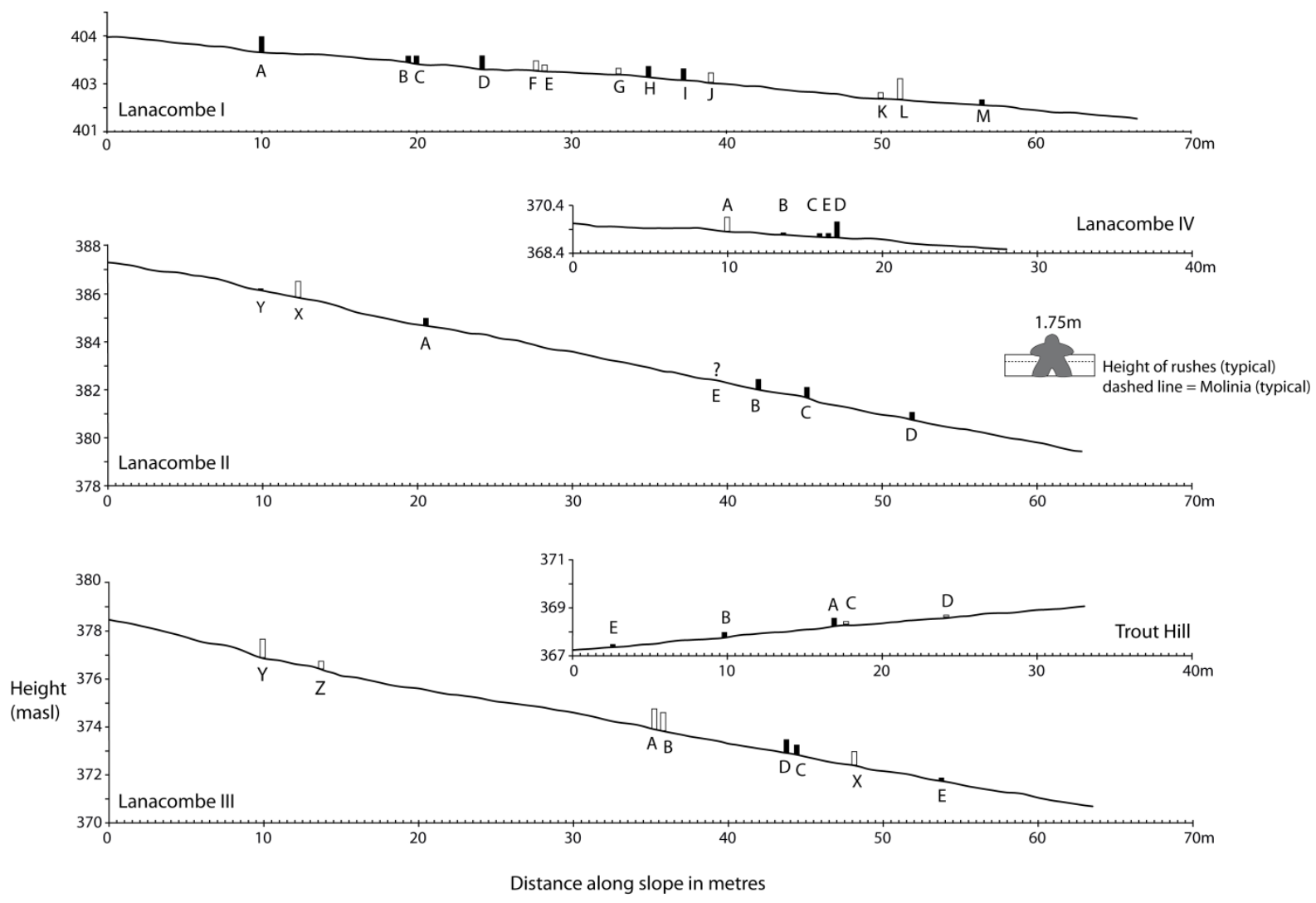

Figure 9 -Vertical profiles along the main axis of the Lanacombe monuments showing relative stone positions and heights. Open boxes indicate now fallen stones - the original height has been estimated by subtracting $0.1 \mathrm{~m}$ from the maximum dimension. The typical vegetation heights were measured during late September. 


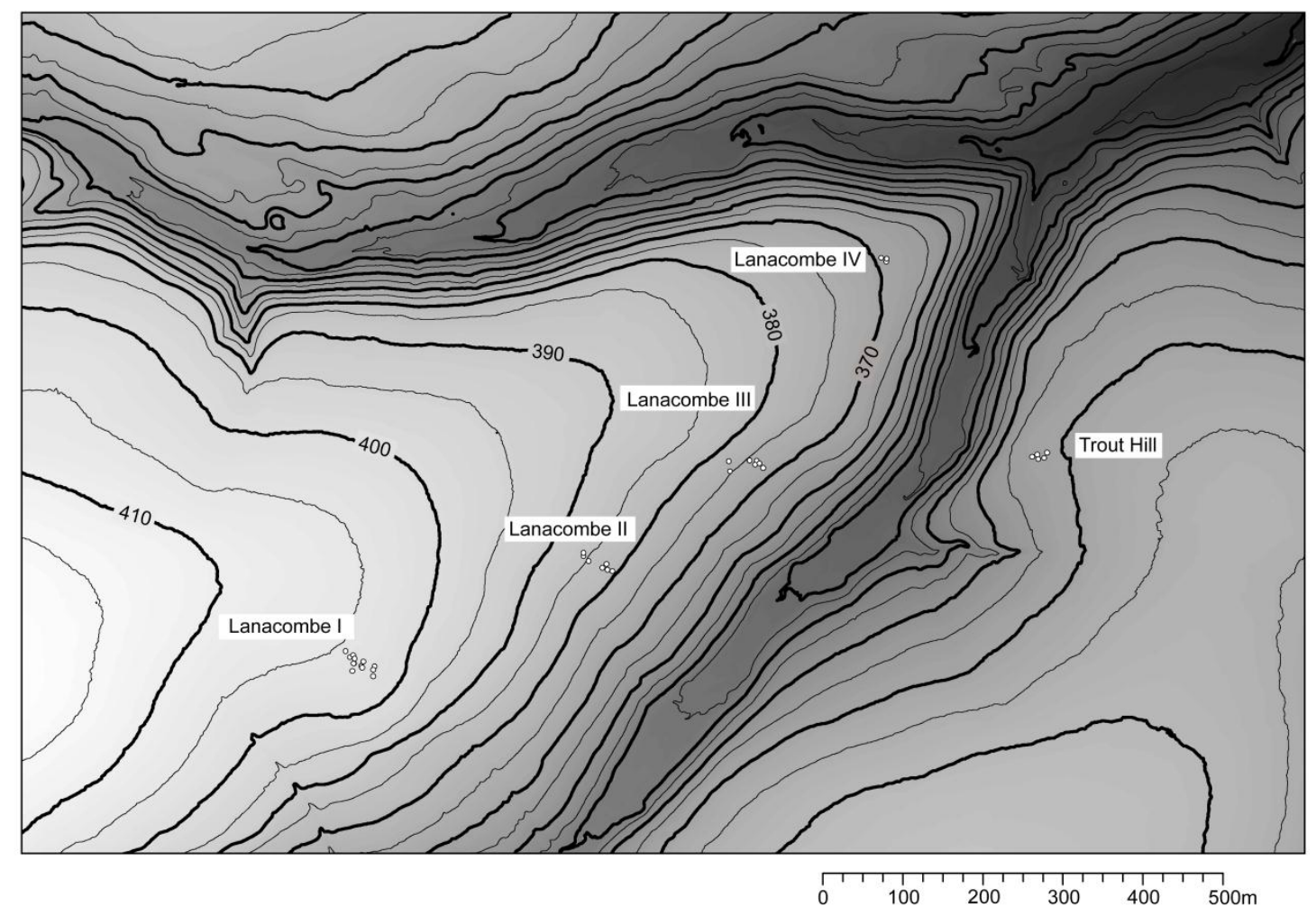

Figure 10 - The location of the settings, stepping progressively down the slope relative to the contours. 


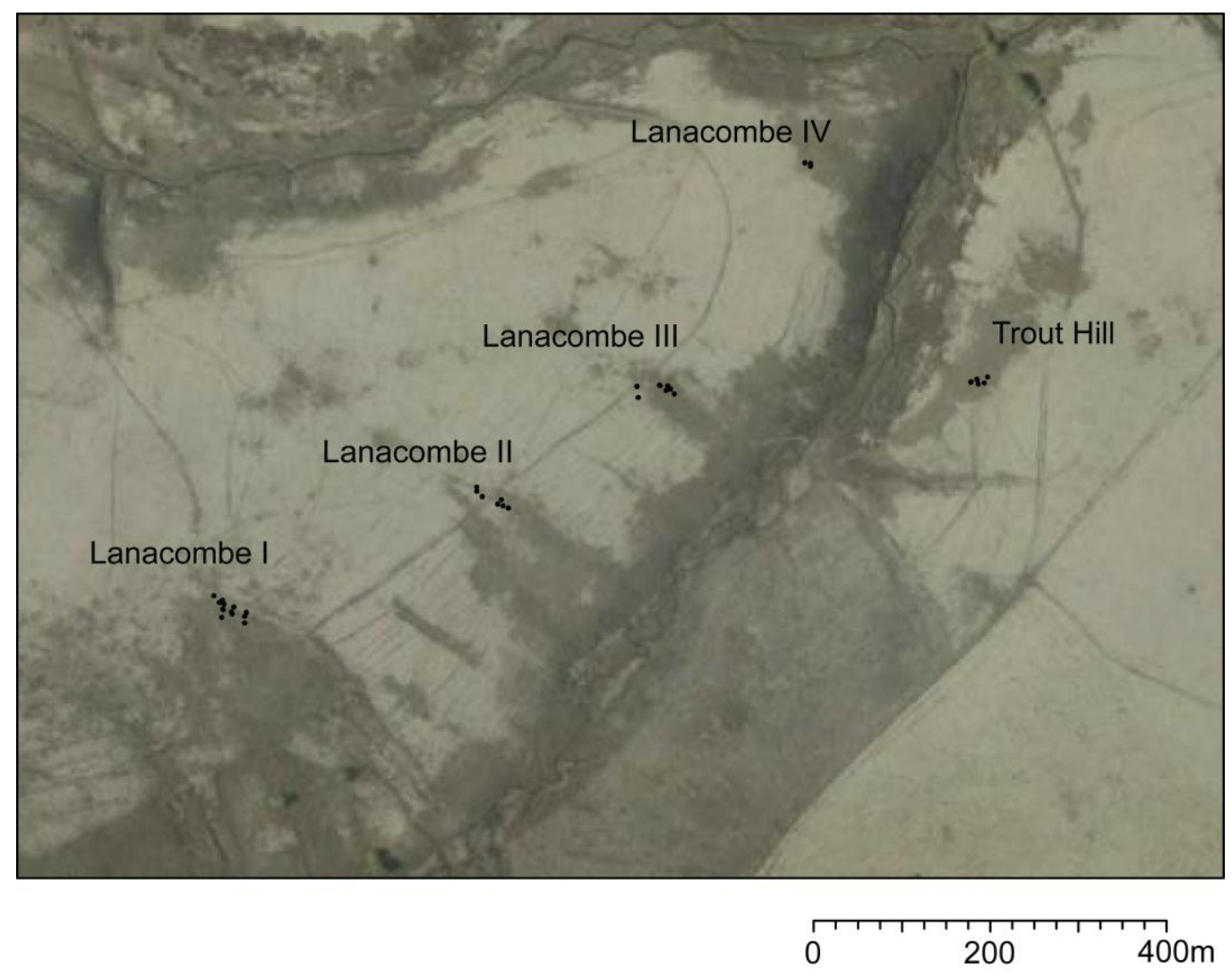

Figure 11 - The exclusive correlation between setting locations and the vegetation changes (darker) that at certain time of year mark the bands of shallower bedrock detected by geophysical survey (Gillings et al. 2010; Gillings 2013) (image extracted from Google Earth June 2014). 